\title{
How to Improve Monitoring and Enforcement of International Labour Standards?
}

\author{
Bernd Waas
}

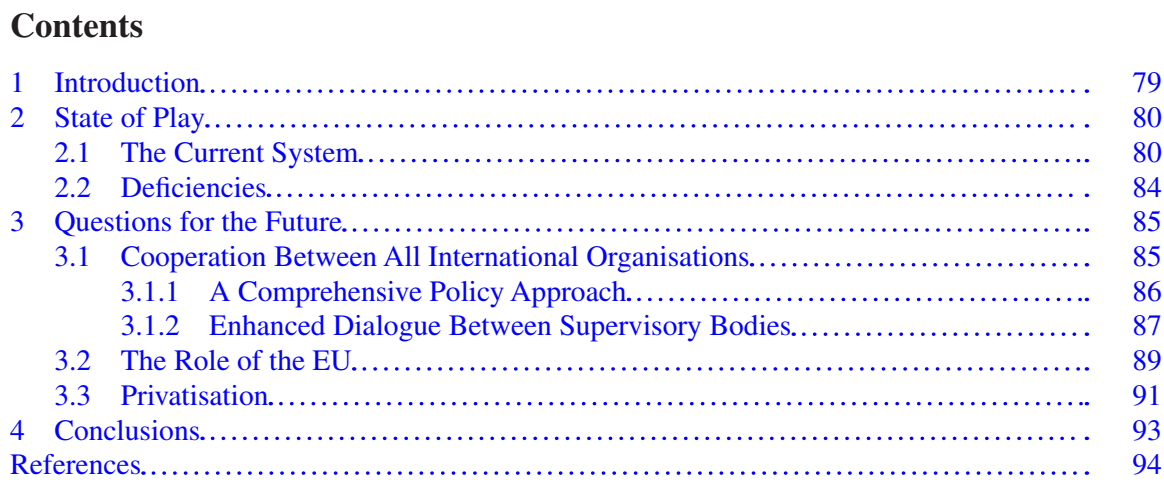

\section{Introduction}

International labour standards are important and deserve every effort to ensure monitoring and enforcement. The fundamental objective of the ILO, which owes its existence to the Treaty of Versailles and is therefore directly linked to the tragedy of World War I, is set out in the preamble to the Constitution. Its first sentence reads: "In the long run, world peace can only be built on social justice". Who would deny that today? A certain reorientation of the goals of the ILO then took place, under the impression of the Second World War, with the Philadelphia Declaration of 1944. Its much quoted first principle is: "Work is not a commodity". This statement seems more relevant today than ever. Global value chains, the increasing importance of artificial intelligence and the expanding platform economy clearly open up opportunities, but at the same time they are accompanied by considerable risks for working people. These risks should remind us of our task to ensure that work does not become a commodity in the future.

\footnotetext{
B. Waas $(\square)$

Goethe University, Frankfurt am Main, Germany

e-mail: waas@jur.uni-frankfurt.de
} 
To achieve this, two things are needed: first, the existence of international standards that take into account the realities of current labour markets, and second, adequate monitoring and effective enforcement of those standards. This chapter is devoted to the issue of monitoring and enforcement. It starts by outlining the existing system (Sect. 2) and then looks at how better monitoring and enforcement could be ensured in the future (Sect. 3). Three issues will be addressed in this regard: improved cooperation between international organisations and, in particular, enhanced dialogue between courts and other supervisory bodies; the EU's contribution to the enforcement of international labour standards; and the role of the private sector in the monitoring and enforcement of these standards. Let us start with a stocktaking exercise.

\section{State of Play}

\subsection{The Current System}

Within the ILO, monitoring and enforcement of international labour standards have changed over time. The system in place today works well on balance. However, the system is quite complex, at least at first sight: different bodies are responsible for monitoring standards and there are specific as well as general monitoring mechanisms. This cannot be set out here in detail. Instead, I will limit myself to a brief sketch.

If there is a possible violation of freedom of association, the Committee on Freedom of Association (CFA) will be responsible. So far, the Committee has commented on about 3200 cases. $^{1}$ The Committee was established in 1951 by the Governing Body of the ILO. This decision was based on an agreement between the ILO and the UN that a specific procedure should be established to ensure effective monitoring of Member States' obligations to ensure freedom of association. ${ }^{2}$ The Committee's task is to determine "whether any given legislation or practice complies with the principles of freedom of association and collective bargaining laid down in the relevant Conventions". ${ }^{3}$ The establishment of the CFA reflects the fundamental importance that the ILO attaches to these guarantees. The Committee on Freedom of Association has a tripartite structure and its members are representatives of the governments of the ILO member states as well as representatives of workers and employers. The Chairman of the Committee is independent.

In addition to the Committee on Freedom of Association, there are two other main players. As part of the general monitoring process, these actors have shared

\footnotetext{
${ }^{1}$ Cf. ILO (2018).

${ }^{2}$ Cf. Beaudonnet (2010), p. 73.

${ }^{3}$ ILO, Special procedures for the examination in the International Labour Organization of complaints alleging violations of freedom of association - Annex 1 (no. 14).
} 
responsibilities: The Committee of Experts on the Application of Convention and Recommendations (CEACR or Committee of Experts) and the Conference Committee on the Application of Standards (CAS). General monitoring is based on reports which, under the Constitution of the ILO, the members have to submit at regular intervals. ${ }^{4}$ The report must contain the following information: an indication of the relevant laws, regulations and other legal sources (including copies); exceptions and the like, where permitted by the relevant Convention; information on the implementation of each individual provision of a Convention in national law; details of the legal effects of ratification of the Convention under national law; responses to possible opinions of the Committee of Experts; information on the bodies responsible for enforcement of a Convention; relevant decisions by courts and administrative authorities; details of any results of assistance or advice given in the context of ILO technical cooperation projects; a general assessment of the application of the Convention (including extracts from official reports, statistics, details of violations, prosecutions, and the like)..$^{5}$ In addition, the reports must be accompanied by copies of observations made by employers' and workers' organisations. ${ }^{6}$

As already mentioned, the task of monitoring standards is carried out on the one hand by the Committee of Experts and on the other hand by the Conference Committee on the Application of Standards. Both committees are strictly separated, but work together. There is, however, a clear division of roles. This is explained by the different structures and tasks of the two bodies: the conference committee has a tripartite structure and bases its decisions partly on aspects of opportunity. The Committee of experts consists of independent experts. It carries out its assessment exclusively from a legal point of view. This background is necessary in order to understand that the Committee of Experts has repeatedly invoked in its reports a "spirit of mutual respect, cooperation and responsibility"7: the wording takes account of the joint responsibility of the two institutions for monitoring international standards, but at the same time makes it clear that the Committee attaches importance to its independence.

Anyone who deals with future issues should also consider the past. This also applies to the question of future monitoring and enforcement of international standards: In the early days of the ILO, there was no system for monitoring standards. It was not until 1926 that, against the background of an increasing number of

\footnotetext{
${ }^{4}$ See Art. 22 of the Constitution of the ILO: "Each of the Members agrees to make an annual report to the International Labour Office on the measures which it has taken to give effect to the provisions of Conventions to which it is a party. These reports shall be made in such form and shall contain such particulars as the Governing Body may request."

${ }^{5} \mathrm{Cf}$. ILO (2019a), p. 25 et seq.

${ }^{6}$ Cf. Art. 23(2) of the Constitution of the ILO: "Each Member shall communicate to the representative organizations recognized for the purpose of article 3 copies of the information and reports communicated to the Director-General in pursuance of articles 19 and 22."

${ }^{7}$ See, e.g., Committee of Experts on the Application of Conventions and Recommendations (2018), para 13.
} 
ratifications, the ILO was to establish such a system. ${ }^{8}$ Two institutions were formed at that time: The Conference Committee and-initially only on a temporary basisthe Committee of Experts, which met for the first time in 1927 (with eight members). As already indicated above, the (tripartite) Conference Committee was always understood to be a political body. On the other hand, the Committee of Experts should ensure an independent legal analysis ${ }^{9}$ and, in particular, uncover different interpretations of the provisions of the Convention in the Member States. ${ }^{10}$ The Committee should include its observations in a "technical report" to be submitted to the Director. Great care was taken to set narrow limits for the Committee: Under no circumstances should the Committee be allowed to subpoena government representatives. It should also limit its work entirely to the information provided by governments. ${ }^{11}$ From the outset, there were concerns that the new committee could undermine members' sovereign rights and interfere in other ILO bodies' reserved areas. These concerns were allayed, in particular, by emphasising that the committee should in no way be a court-like body. ${ }^{12} \mathrm{~A}$ fundamental reform then took place as a result of far-reaching changes to the ILO Constitution in 1946, which greatly expanded the reporting obligations of its members. As a result, the mandates both of the Conference Committee and of the Committee of Experts were extended. The task of the Committee of Experts is to indicate to what extent the legislation and practice of each member is in conformity with the ratified conventions and to what extent the members have fulfilled their norm-related obligations under the ILO Constitution. The Committee of Experts should serve as an "intermediate stage in

\footnotetext{
${ }^{8} \mathrm{Cf}$. Resolution concerning the methods by which the Conference can make use of the reports submitted under Article 408 of the Treaty of Versailles, submitted by the Committee on Article 408. In: ILO (1926) International Labour Conference, Record of Proceedings, 8th Session, Geneva, 26 May-5 June 1926, p. 429.

${ }^{9}$ Cf. ILO (1926) International Labour Conference, Record of Proceedings, 8th Session, Geneva, 26 May-5 June 1926, p. 396: "Further, it may be observed that the Conference and its Committees are essentially deliberative and political bodies, composed of the representatives of various interests, national or occupational, and that in general such bodies are not the best suited for the technical work now under consideration." Cf. also, p. 398: "The Committee of Experts might therefore be, not a committee set up directly by the Conference, but a committee created by the Director, on the instructions of the Conference and with the approval of the Governing Body, to carry out a particular task in view of the technical preparation of one part of the work of the Conference. The Conference itself would conserve its proper political functions, but it would be advised as to the facts by this technical expert Committee, and it would, either directly, or through one of its own Committees, decide upon its attitude and upon what appropriate action it might take or indicate."

${ }^{10}$ Ibid., p. 401: "Its examination will certainly reveal cases in which different interpretations of the provisions of Conventions appear to be adopted in different countries. The Committee should call attention to such cases."

${ }^{11}$ Ibid., p. 401: "[...] there is and can be no question of convoking Governments or their representatives before the proposed Committee, which would base its reports entirely upon the information which the States have undertaken in ratifying the Convention, to supply."

${ }^{12}$ Ibid., p. 405: "It was agreed [...] that the Committee of experts would have no judicial capacity nor would it be competent to give interpretations of the Conventions not to decide in favour of one interpretation rather than of another."
} 
the monitoring process" and prepare the review of the application of the Conventions by the Conference Committee. ${ }^{13}$

The Committee of Experts, currently composed of 20 independent members, meets once a year for some 3 weeks to review the reports submitted by members. The meetings of the Committee are not open to the public. Committee deliberations and documents are confidential. ${ }^{14}$ The Office provides the Committee members with considerable support in fulfilling their tasks. In fact, one simply cannot praise the office and its staff enough for its input. The work of the Committee of Experts results in opinions, for which a distinction is made between observations and direct requests. Observations are usually used in serious or long-standing cases of noncompliance. They are included in the report of the Committee, which is submitted to the Conference Committee each year in June of the following year and is also published as part of the Annual Report. Direct requests, on the other hand, are sent directly to the government concerned. They are not included in the annual report. ${ }^{15}$ Unlike direct requests, observations are normally used in serious or protracted cases of non-compliance. In this regard, so-called "special notes", which are traditionally referred to as footnotes, are of particular importance. In the case of a so-called single footnote, the Committee requests an earlier report from the government. A double footnote even asks a government to provide comprehensive and detailed information at the next International Labour Conference. In answering the question whether one or the other type of footnote should be considered, the Committee takes into account, among other things, the seriousness of the problem (in particular with regard to the interests involved); the persistence of the problem; the duration and urgency of the situation; and the type of reaction by a Member State. ${ }^{16}$

The comments of the Committee of Experts form the basis for the work of the Conference Committee. The Conference Committee discusses problems arising in the implementation of agreements and recommendations on the basis of the report submitted by the Committee of Experts. Most importantly, the comments of the Committee of Experts form the basis for selection of cases to be further discussed at the International Labour Conference, which takes place every year. In practice, the Conference Committee selects approximately 20 cases each year for closer inspection. Since 2012, discussion of these cases by the International Labour Conference Committee has started with cases which have been given a double footnote by the Committee of Experts. ${ }^{17}$

It should not be concealed that the mandate of the Expert Committee is not uncontroversial within the ILO. Dispute was sparked by the fact that the Committee derives a right to strike from Convention No 87, although that right is not explicitly

\footnotetext{
${ }^{13}$ International Labour Office (1947) Minutes of the 103rd Session of the Governing Body, Geneva, December 1947, p. 169 et seq.

${ }^{14}$ Cf. ILO (2019a), p. 35 et seq.

${ }^{15}$ Cf. Ibid., p. 36.

${ }^{16}$ Committee of Experts on the Application of Conventions and Recommendations (2018), para 45 et seq.

${ }^{17}$ Cf. ILO (2019a), p. 38 et seq.
} 
mentioned in the Convention. It has to be said, without any accusation of guilt, that the dispute is highly regrettable because it creates the danger that the credibility and authority of the supervisory bodies could be damaged. The Committee of Experts itself takes the following view with regard to its mandate:

The Committee of Experts on the Application of Conventions and Recommendations is an independent body established by the International Labour Conference and its members are appointed by the ILO Governing Body. It is composed of legal experts charged with examining the application of ILO Conventions and Recommendations by ILO member States. The Committee of Experts undertakes an impartial and technical analysis of how the Conventions are applied in law and practice by member States, while cognizant of different national realities and legal systems. In doing so, it must determine the legal scope, content and meaning of the provisions of the Conventions. Its opinions and recommendations are non-binding, being intended to guide the actions of national authorities. They derive their persuasive value from the legitimacy and rationality of the Committee's work based on its impartiality, experience and expertise. The Committee's technical role and moral authority is well recognized, particularly as it has been engaged in its supervisory task for more than 90 years, by virtue of its composition, independence and its working methods built on continuing dialogue with governments taking into account information provided by employers' and workers' organizations. This has been reflected in the incorporation of the Committee's opinions and recommendations in national legislation, international instruments and court decisions. ${ }^{18}$

\subsection{Deficiencies}

It was stated above that the standards monitoring system works. This does not mean, however, that there is no room for improvement. For example, it is clear that many Member States are not meeting their reporting obligations, are not meeting them on time, or are not meeting them to the required extent. The report of the Committee of Experts for the year 2018 reports with concern the high number of reports that were not received on time so that cases had to be deferred. ${ }^{19}$ At the same time, the workload of the Committee of Experts and the Office is enormous. As a result, a considerable number of reports cannot be dealt with promptly by the Committee. Instead, their examination is postponed to the following year. To remedy this or at least mitigate the adverse consequences is an ongoing task that has led to a number of changes, particularly in recent times. For instance, the decision was taken a while ago to extend the so-called "reporting cycles". ${ }^{20}$ There have also been some reforms

\footnotetext{
${ }^{18}$ Cf., e.g., Committee of Experts on the Application of Conventions and Recommendations (2018), para 19.

${ }^{19}$ Ibid., para 25 et seq.

${ }^{20}$ The Governing Body of the ILO decided some time ago to extend the reporting cycle to 6 years. See International Labour Office (2018) Fifth Item on the Agenda - The Standards Initiative: Implementing the workplan for strengthening the supervisory system Progress report. In: Decisions adopted by the Governing Body at its 334th Session and outcomes of the discussions, Geneva, 25 October-8 November 2018.
} 
of a more technical nature, such as increased use of electronic tools or the creation of teams of members of the Committee of Experts or the grouping of Conventions for the purpose of examination by the Committee members.

In all this, it should also be borne in mind that the Committee of Experts does have considerable room for manoeuvre in its work as the committee has no rules of procedure. Rather, the committee itself decides on its own "working methods". To this end, a subcommittee was set up in 2001 to deal in detail with issues relating to the organisation of the work of the Committee. In practice, all members of the Committee of Experts attend meetings of the Subcommittee, which may serve as an indication that working methods are understood to be of utmost importance.

\section{Questions for the Future}

The problem of monitoring and enforcing international standards is (almost) as old as the standards themselves. However, this task will not be easier to accomplish. With the rapid advance of digitisation, work is becoming a shy deer, making it increasingly difficult not only to regulate, but also to monitor and enforce the relevant standards. The fact that technological advances also offer some opportunities in this respect- the Global Commission in its report refers, among other things, to the virtues of blockchain technology ${ }^{21}$-is a rather weak consolation. What is certain is that international standards will increasingly aim to regulate transnational issues and that, accordingly, cooperation between the ILO member states across borders will be necessary in the enforcement of these standards, as is already the case today, for example, within the framework of the Maritime Labour Convention of 2006, where the enforcement regime is based on shared enforcement of maritime labour conditions by flag and port States. ${ }^{22}$

\subsection{Cooperation Between All International Organisations}

Bur monitoring of standards requires more, namely ever-intensive cooperation between all international organisations. The first step should be to develop an approach that goes beyond individual policy areas to ensure that efforts in one area are not thwarted by efforts in another. Rather than that, synergies should be sought.

\footnotetext{
${ }^{21}$ ILO (2019b), p. 44.

${ }^{22}$ See Title 5 of the Maritime Labour Convention, 2006.
} 


\subsubsection{A Comprehensive Policy Approach}

Such fruitful cooperation already exists on many levels. The OECD deserves a positive mention in this respect. ${ }^{23}$ Here there are examples not only of the fact that core labour standards have been given additional legitimacy, but also of the fact that independent pressure has been exerted to urge states to comply with labour standards. In one case, for example, membership of the organisation was made conditional on the particular state showing greater respect for freedom of association. The OECD Guidelines for Multinational Enterprises in its Commentary section explicitly acknowledge the work of the ILO by expressly stating that it is the ILO which is "the competent body to set and deal with international labour standards, and to promote fundamental rights at work". The Guidelines, the text goes on to say, "have a role to play in promoting observance of these standards and principles among multinational enterprises". ${ }^{24}$

While in the relationship between the ILO and the OECD the idea of cooperation is predominant, the picture is less positive when it comes to other international organisations which are also becoming increasingly involved in the social arena. ${ }^{25}$ The relationship between the IMF and the World Bank and the latter's position with regard to international labour standards has been relatively well researched in the literature. There, it has repeatedly been pointed out that compliance with international labour standards is in a certain tension with the deregulation of labour markets, which is predominantly favoured by both the World Bank and the IMF. In addition, a number of studies suggest that structural adjustment programmes fostered by the two institutions have come with a decline of labour rights protection in the countries concerned. ${ }^{26}$

The relationship between the ILO and WTO and the importance of international standards in the area of free trade agreements is a chapter in itself. It is well known that attempts to integrate "social clauses" into such agreements within the framework of the WTO have so far been unsuccessful. ${ }^{27}$ This is mainly due to the fact that the member states assess such clauses very differently. Developed countries are usually in favour. Developing countries, however, argue that the attempt to bring labour issues into the WTO is actually a bid by industrial nations to undermine the comparative advantage associated with lower social standards and that efforts to bring labour standards into the arena of multilateral trade negotiations are little more than a smokescreen for protectionism. At the same time, there is a fear among them that the proposed standards may be too ambitious. That a consensus could emerge in the near future seems unlikely. But perhaps we can still allow ourselves a

\footnotetext{
${ }^{23} \mathrm{Cf}$. in this regard Thouvenin (2015), p. 385.

${ }^{24}$ OECD (2011), p. 37. On the other hand, the revised Tripartite Declaration of Principles concerning Multinational Enterprises and Social Policy includes a reference to the OECD Guidelines.

${ }^{25}$ Cf. Chen (2018), p. 184.

${ }^{26}$ Cf. Ebert (2018), pp. 273-274 with further references (footnote 3); see also Ebert (2015), p. 124.

${ }^{27}$ Cf. Stoll (2018), pp. 11-27.
} 
brief dream and imagine for a moment that progress could indeed be made within the framework of the WTO on international standards whose justification as such must be completely undisputed. Think, for example, of proposals from legal circles aiming at establishing a joint ILO-WTO implementation mechanism to combat child labour. It has been suggested in the literature that such a mechanism in certain cases such as export-related child labour could be subject to dispute settlement resulting in trade measures as measures of last resort. In addition to the intergovernmental dispute settlement system, there would also be a private complaints mechanism where non-governmental organisations on behalf of children could bring certain complaints against companies and governments. Panels would include ILO experts and decisions would be based on UN and ILO jurisprudence. Complaints against governments could result in dispute resolution ending with trade measures. ${ }^{28}$ If only such a scenario could come true!

In any case, any attempt to bring about more intensive cooperation is worthwhile. In view of this, one can only endorse the Global Commission on the Future of Work. It writes in its report:

We recommend in particular the establishment of more systemic and substantive working relations between the World Trade Organization (WTO), the Bretton Woods institutions and the ILO. There are strong, complex and crucial links between trade, financial, economic and social policies. The success of the human- centred growth and development agenda we propose depends heavily on coherence across these policy areas. ${ }^{29}$

There is nothing to add to that.

\subsubsection{Enhanced Dialogue Between Supervisory Bodies}

However, it is not only international organisations as such that are called upon to intensify cooperation, but also the courts and other international supervisory bodies set up to monitor international standards should enter into intensified dialogue with each other. In particular, these bodies would be well advised not to lead a life of their own, but also to orient themselves to findings by others in the performance of their supervisory tasks. In this regard, one could take a leaf out of the book of the practice of the European Court of Human Rights (ECtHR).$^{30}$ In 2008, for example, the Court, in its decision in Demir and Baykara (on the establishment of a trade union by employees of a municipality), expressly stated that in interpreting the provisions of the ECHR, the Court "can and must take into account elements of international law other than the Convention, the interpretation of such elements by competent organs, and the practice of European States reflecting their common values". The Court went on to say: "The consensus emerging from specialised international instruments and from the practice of Contracting States may constitute a

\footnotetext{
${ }^{28}$ See Humbert (2018), pp. 93-109.

${ }^{29}$ ILO (2019b), p. 14.

${ }^{30}$ For more details, see Teklè (2018), p. 236; Waas (2019), pp. 123-147.
} 
relevant consideration for the Court when it interprets the provisions of the Convention in specific cases." ${ }^{11}$ In doing so, the ECtHR orientates itself not least on the rulings of the CFA and CEACR. All this does not mean that differences between the different panels should not be taken into account. The ECtHR itself at times has emphasised differences between the Court of Justice on the one hand and ILO supervisory bodies on the other. According to the ECtHR, ILO supervisory bodies have "to review the relevant domestic law in the abstract", whereas the court has to decide on a concrete legal dispute. ${ }^{32}$ In spite of these differences, the Court takes the rulings of ILO supervisory bodies into consideration. In the Enerji Yapi-Yol Sen case, for example, in 2009 the Court recognised the right to strike for civil servants by, among other things, referring to the ILO supervisory bodies. ${ }^{33}$ The most recent example of a reference by the ECtHR to the findings of the Committee of Experts is the decision of the Court of Justice in the Ognovenko case concerning the legality of strikes in Russian rail transport. In this respect, the Court recalls that the Committee does not regard the railway sector as an "essential service" in which strikes could be banned and that the Committee has for some time been calling on Russia to ensure that railway workers could exercise their right to strike. ${ }^{34}$

Basically, the same applies to the European Committee of Social Rights. This will not be substantiated in detail here. Instead, I would like to take the liberty of quoting Monika Schlachter, a former long-standing member of the ECSR. In a recent article, she came to the following conclusion:

The ILO Committees [...], the ECHR and the ECSR are increasingly orienting themselves towards the goal of greater convergence in the concretisation and development of social rights by using the historically close link between social protection rights for their interpretation. This applies in particular to the interpretation results developed by the ILO monitoring bodies, which are used at both international and national level to concretise social rights. ${ }^{35}$

The CJEU stands in striking contrast to this. For instance, in the "famous" Laval and Viking rulings, the CJEU derived a right to strike from, among others, ILO Convention No. 87, although that right is not expressly mentioned in the Convention. ${ }^{36}$ In this respect, it would have been self-evident to refer to the stance

\footnotetext{
${ }^{31}$ European Court of Human Rights (Grand Chamber), Demir and Baykara v. Turkey (App. No. 34503/97), Judgment, 12 November 2008, para 85.

${ }^{32}$ European Court of Human Rights (Fourth Section), National Union of Rail, Maritime and Transport Workers v. The United Kingdom (App. No. 31045/10), Judgment, 8 April 2014, para 95.

${ }^{33}$ European Court of Human Rights (Third Section), Enerji Yapi-Yol Sen v. Turkey (App. No. 68959/01) (Enerji Yapi-Yol Sen/Türkei), Judgment, 21 April 2009, para 24.

${ }^{34}$ European Court of Human Rights (Third Section Ognovenko v. Russia (App. No. 44873/09), Judgment, 20 November 2018, para 22 et seq.

${ }^{35}$ Schlachter (2019), pp. 491-494.

${ }^{36} \mathrm{CJEU}$ (Grand Chamber), Laval un Partneri Ltd v Svenska Byggnadsarbetareförbundet, Svenska Byggnadsarbetareförbundets avdelning 1, Byggettan and Svenska Elektrikerförbundet (Case C-341/05), Judgment, 18 December 2007, para 90; CJEU (Grand Chamber), International Transport Workers' Federation and Finnish Seamen's Union $v$ Viking Line ABP and OÜ Viking Line Eesti (Case C-438/05), Judgement, 11 December 2007, para 43.
} 
of the Committee of Experts, which in fact affirms that very right. However, this is precisely what the CJEU did not do.

\subsection{The Role of the EU}

A look at the limited reception of international labour law directs attention to the European Union as such. What could the EU do to help enforce international standards? Let us dream for a moment and ask: Would anything perhaps be gained if the EU as such were to join the ILO and then ratify all the ILO conventions? The question seems bold, almost absurd. But to raise such questions is the privilege of the academic. Nevertheless, the idea should not be pursued here. Apart from the question whether accession really would have predominantly positive effects on the enforcement of standards, there would be so many legal and political obstacles to accession that one can immediately say goodbye to that idea. By contrast, it would seem somewhat more realistic to open ILO conventions to future accession by regional organisations such as the EU. There would even be a role model for that. For the first time in a human rights convention with worldwide validity, the Convention on the Rights of Persons with Disabilities of 2006 allows "regional integration organizations $"{ }^{37}$ to also accede to the convention. ${ }^{38}$ And indeed, the EU is the first international organisation that made use of the possibility of accession and ratified it, in 2011. ${ }^{39}$ Ever since, the CJEU has repeatedly used the Convention to interpret Union law. ${ }^{40}$

Instead of binding itself externally, however, the EU could also enter into a kind of "self-commitment". There would also be role models for this. In fact, there are already two directives which, by taking over a large part of the content of a convention, produce an almost identical result to ratification by the EU. Both directives concern issues of maritime labour law. To begin with, Directive 2009/13/EC was adopted to implement an agreement between the relevant social partners in the industry, which for its part largely adopts the 2006 ILO Maritime Labour Convention. ${ }^{41}$ As a result, the Directive incorporates large parts of the Maritime

\footnotetext{
${ }^{37}$ See Art. 44(1) of the Convention on the Rights of Persons with Disabilities: "'Regional integration organization' shall mean an organization constituted by sovereign States of a given region, to which its member States have transferred competence in respect of matters governed by the present Convention."

${ }^{38}$ Ibid., Art. 42.

${ }^{39}$ See Council of the European Union, Council Decision 2010/48/EC of 26 November 2009 concerning the conclusion, by the European Community, of the United Nations Convention on the Rights of Persons with Disabilities. In Official Journal of the European Union (2010) L 23, p. 35.

${ }^{40}$ See, e.g., CJEU (First Chamber), DW v Nobel Plastiques Ibérica SA (Case C-397/18), Judgment, 11 September 2019.

${ }^{41}$ Council of the European Union, Council Directive 2009/13/EC of 16 February 2009 implementing the Agreement concluded by the European Community Shipowners' Associations (ECSA) and
} 
Labour Convention into Union law. As a matter of fact, EU representatives were actively involved in the preparation of the Maritime Labour Convention. Following adoption of the Convention by the International Labour Conference, the EU Council then authorised the Member States to ratify the Maritime Labour Convention. This authorisation was necessary internally, as areas that are regulated by the Convention fall within the exclusive competence of the Union, thus giving the EU exclusive external competence. Almost identical to incorporation of the Maritime Labour Convention into Directive 2009/13/EC is the incorporation of important provisions of Convention No. 188 on work in the fisheries sector into Directive 2017/159/ EU. Convention 188 was adopted by the International Labour Conference in 2007. Despite the low level of ratification by EU Member States at the time, in 2012 the relevant social partners reached agreement to incorporate Convention 188 into Union law. ${ }^{42}$ The agreement is largely identical in wording to the Convention and was incorporated into Directive 2017/159/EU. The Directive entered into force at the same time as Convention No. 188, on 16 November 2017. It is also welcome, by the way, that the European Commission recently encouraged Member States to ratify the Violence and Harassment Convention, 2019 (No. 190) of the ILO. ${ }^{43}$

An examination of the relationship between the ILO and the EU would be incomplete, however, if one did not also say a word about the significance of ILO standards in the area of the EU customs system. This leads us to the so-called Generalised System of Preferences of the European Union, which grants special tariff advantages to developing countries. According to this system, developing countries receive simplified access to the European market from the EU (so-called "standard GSP"), while the least developed countries are in principle completely free to import into the EU the so-called EBA, the acronym standing for "Everything But Arms", the special arrangement for least developed countries, providing them with dutyfree, quota-free access for all products except arms and ammunition. Countries in the GSP category can be granted additional trade benefits provided they comply with certain special arrangements for sustainable development and good governance (so-called "GSP+"). In any case, access to the EU market is conditional on compliance with the eight Conventions that specify the ILO core labour standards. For example, a country wishing to obtain additional benefits under the GSP+ system must ratify and comply with the eight Conventions. ${ }^{44}$ In the event of "serious

the European Transport Workers' Federation (ETF) on the Maritime Labour Convention, 2006, and amending Directive 1999/63/EC. In Official Journal of the European Union (2009) L124, p. 30.

${ }^{42}$ Council of the European Union, Council Directive (EU) 2017/159 of 19 December 2016 implementing the Agreement concerning the implementation of the Work in Fishing Convention, 2007 of the International Labour Organisation, concluded on 21 May 2012 between the General Confederation of Agricultural Cooperatives in the European Union (Cogeca), the European Transport Workers' Federation (ETF) and the Association of National Organisations of Fishing Enterprises in the European Union (Europêche). In Official Journal of the European Union (2017) L25, p. 12.

${ }^{43}$ European Commission (2020).

${ }^{44}$ See Annex VIII of Reg. (EU) No 978/2012 of the European Parliament and of the Council of 25 October 2012 applying a scheme of generalised tariff preferences and repealing Council Regulation 
breaches in the effective application" of the Conventions, the Commission may temporarily withdraw GSP+ status. ${ }^{45}$ In all other cases, the conventions do not need to be ratified. However, should "serious and systematic breaches of principles" of the Conventions be identified, these preferences may also be temporarily suspended. ${ }^{46}$ Compliance with the agreements is monitored by the Commission. In accordance with the explicit provisions of Regulation 978/2012, the Commission should in particular also take into account the conclusions of the ILO committees.

On paper, this system seems highly convincing. However, there are doubts as to its practical effectiveness in light of the fact that so far none of the beneficiary countries seems to have lost their GSP+ status due to violations of the CLS conventions or other human rights conventions. ${ }^{47}$ However, there is also another cause for concern: while the Commission has dealt in detail with assessments of the ILO supervisory organs in the past, the current report, for the years 2016 and 2017, disturbingly no longer refers to the conclusions of the ILO committees to the same extent. And while the country-specific reports for 2016 and 2017 provide a precise account of the latest observations and direct requests by the CEACR that exist for each of the countries, the Commission does not take into account that in both 2016 and 2017 one GSP+ beneficiary country was included in the list of the most serious violations of conventions by the CAS.

\subsection{Privatisation}

If one considers the monitoring and enforcement of international standards, one cannot avoid a phenomenon that is often described as privatisation. ${ }^{48}$ The numerous codes of conduct and labels relating to good working conditions are particularly relevant in this context. Privatisation is now so significant that some people are already claiming that a "consumocratic labor law" has emerged. Dumas described this as follows:

\footnotetext{
(EC) No 732/2008.

${ }^{45}$ See Art. 9(1) of Reg. (EU) No 978/2012 of the European Parliament and of the Council of 25 October 2012 applying a scheme of generalised tariff preferences and repealing Council Regulation (EC) No 732/2008: "A GSP beneficiary country may benefit from the tariff preferences provided under the special incentive arrangement for sustainable development and good governance [...] (b) if it has ratified all the conventions listed in Annex VIII (the 'relevant conventions') and the most recent available conclusions of the monitoring bodies under those conventions (the 'relevant monitoring bodies') do not identify a serious failure to effectively implement any of those conventions $[\ldots] . "$

${ }^{46}$ See Ibid.: "The preferential arrangements referred to in Article 1(2) may be withdrawn temporarily, in respect of all or of certain products originating in a beneficiary country, for any of the following reasons (a) serious and systematic violation of principles laid down in the conventions listed in Part A of Annex VIII [...]."
}

${ }^{47}$ See for more details Stolzenberg (2019), p. 207.

${ }^{48}$ Cf. Diller (2015), p. 329. 
It is called to supplement protective state law when the latter is inappropriately enforced, but also when inappropriately designed, whether the state is incapable or simply unwilling to protect these populations more efficiently. Under a traditional approach to corporate governance, corporations are indeed free to engage in any kind of profitable activity, provided that they do so in accordance with applicable state laws - even if such activity is known to be socially or environmentally harmful by large segments of the citizenry. To an appreciable extent, the resulting detrimental effects are justified by the inaction of more or less representative states. Consumer regulatory power can be seen in this regard as a serious challenge to a deficient though enduring ideology, one under which it is assumed that the failure by the state to correct common market failures leads to undesirable results deemed (wrongly) to be inevitable. ${ }^{49}$

To be honest, I find the concept interesting, but I do not see "consumocratic law", if there is such a thing, as a fully-fledged substitute for robust international standards.

Privatisation of international standards is in any event often also based on the ILO itself. There are now a number of new models of cooperation between the ILO and governments, workers' representatives and industry representatives in which both national and transnational actors work together. One example is the textile and clothing sector, where a number of projects are now aimed at protecting workers interests: The Better Work program is based on a partnership between the ILO and the International Finance Corporation, a member of the World Bank Group. Under that program, buyers in the apparel industry sign up to ILO-monitored inspections of their factories, and agree to public reporting of results. Better Work is governed at international level by a Management Group comprised of ILO and IFC officials, and is guided by an Advisory Committee of representatives of donor governments, international employers and workers organisations, buyers and independent experts. ${ }^{50}$

Another example is the Accord on Fire and Building Safety in Bangladesh. This agreement was signed in 2013 in the aftermath of the Rana Plaza building collapse that led to the death of more than 1100 people and injured more than 2000. In 2017 a further agreement was concluded, which builds on the previous one. ${ }^{51}$ The agreement consists of six key components: A five-year legally binding agreement between brands and trade unions to ensure a safe working environment in the Bangladeshi ready-made garment industry; an independent inspection program; public disclosure of all factories, inspection reports and corrective action plans; a commitment by signatory brands to ensure sufficient funds are available for remediation and to maintain sourcing relationships; establishment of health and safety committees in all factories; worker empowerment through an extensive training program; a complaints mechanism; and the right to refuse unsafe work. The Accord is governed by a Steering Committee with equal representation from trade unions and companies.

\footnotetext{
${ }^{49}$ Dumas (2013), pp. 67-73. See also Dumas (2015), p. 374.

${ }^{50}$ See the Accord on Fire and Building Safety in Bangladesh, 2013. Available at: https://admin. bangladeshaccord.org/wp-content/uploads/2018/08/2013-Accord.pdf. Accessed 25 Mar 2020.

${ }^{51}$ See the Accord on Fire and Building Safety in Bangladesh, 2018. Available at: https://admin. bangladeshaccord.org/wp-content/uploads/2018/08/2018-Accord.pdf. Accessed 25 Mar 2020.
} 
The ILO serves as a neutral chair. ${ }^{52}$ An NGO set up by the Accord parties oversees an inspection system financed by the signatory companies. The Government and local industry, though not parties to the agreement, are to be consulted in administration and management of the program. While the Government's inspection standards apply in principle, the ILO helps to coordinate their application in practice among the actors involved and advises on relevant international labour standards.

Privatisation can also be observed in other ways. For instance, the ILO participates in activities to develop private transnational regulatory instruments. The International Organization for Standardization (ISO), which is increasingly developing voluntary standards in areas of social and public order, deserves particular mention in this respect. However, this is a double-edged sword. Since these standards frequently address issues that are also the subject of international labour standards, there is an increasing need to ensure that such initiatives do not conflict with the provisions of the ILS. Without fundamental coordination, the resulting interplay between industrial standards and national ILS-based labour standards could impair the effectiveness of both systems. On the whole, a final judgement on privatisation still seems too early. For instance, it appears to be very promising in the textile and clothing industry. However, the question arises as to whether the success achieved there can easily be transferred to other areas.

International framework agreements can also play a role in the enforcement of international labour standards. In this respect, one should not be discouraged by the fact that the legally binding effect of such agreements is doubtful, so that it is open whether and to what extent it can be enforced before a court or another dispute settlement institution if necessary. Nor does the lack of a transnational legal framework for the enforcement of such agreements necessarily speak against their effectiveness. This does not mean that framework agreements would be ineffective as such as soft law. At least if embedded in "strong and resilient industrial relations", a framework agreement can certainly develop into a flexible instrument and possibly even encourage the actors to come up with new common solutions..$^{53}$ If these conditions are not met, however, there is a real danger that the agreements will remain a "dead letter".

\section{Conclusions}

To conclude with a few final remarks, I would maintain that monitoring and enforcement of standards within the ILO work quite well. But the system is constantly under scrutiny. And that is a good thing. Closer cooperation between international organisations would be desirable. That way, conflicts could be avoided and

\footnotetext{
${ }^{52}$ See No. 4 of the Accord on Fire and Building Safety in Bangladesh, 2013. Available at: https:// admin.bangladeshaccord.org/wp-content/uploads/2018/08/2013-Accord.pdf. Accessed 25 Mar 2020.

${ }^{53}$ Cf. Krause (2018), pp. 319-334.
} 
synergies could be exploited. A deeper dialogue between all relevant courts and supervisory bodies could contribute to a certain convergence of standards. This would not least be in the interest of those subject to the standards themselves. More could also be done at European Union level to enhance the impact of international standards. The successful cooperation between the ILO and the EU could and should be further intensified. Non-governmental actors-non-governmental organisations, the social partners, consumers - can make a major contribution to the enforcement of international labour standards. The importance of these standards cannot be overestimated. Let us always remember: "In the long run, world peace can only be built on social justice".

\section{References}

Beaudonnet X (ed) (2010) International labour law and domestic law: a training manual for judges, lawyers and legal educators. ITC-ILO, Turin

Chen Y (2018) The making of global public authorities: the role of IFIs in setting international labor standards. In: Quayle P, Gao X (eds) AIIB yearbook of international law vol 1: good governance and modern international financial institutions. Brill Nijhoff, Leiden

Committee of Experts on the Application of Conventions and Recommendations (2018) Application of International Labour Standards 2018 - Report III (Part A), International Labour Conference, 107th Session, Geneva, 2018. International Labour Office, Geneva

Diller JM (2015) Pluralism and privatization in transnational labour regulation: experience of the International Labour Organization. In: Blackett A, Trebilcock A (eds) Research handbook on transnational labour law. Edward Elgar, Cheltenham

Dumas PM (2013) Three misunderstandings about consumocratic labor law. Comp Lab Law \& Policy J 35(1):67-92

Dumas PM (2015) Thickening soft law through consumocratic law: a pragmatic approach. In: Blackett A, Trebilcock A (eds) Research handbook on transnational labour law. Edward Elgar, Cheltenham

Ebert FC (2015) International financial institutions' approaches to labour law: the case of the International Monetary Fund. In: Blackett A, Trebilcock A (eds) Research handbook on transnational labour law. Edward Elgar, Cheltenham

Ebert FC (2018) Labour standards and the World Bank. Analysing the potential of safeguard policies for protecting workers. In: Gött $\mathrm{H}$ (ed) Labour standards in international economic law. Springer, Basel

European Commission (2020) Commission encourages EU Member States to ratify the violence and harassment convention. Available at: https://ec.europa.eu/social/main.jsp?langId=en\&catI $\mathrm{d}=89$ \& furtherNews=yes\&newsId=9532. Accessed 25 Mar 2020

Humbert F (2018) The WTO and child labour: implications for the debate on international constitutionalism. In: Gött $\mathrm{H}$ (ed) Labour standards in international economic law. Springer, Basel

ILO (2018) Freedom of association - compilation of decisions of the committee on freedom of association, 6th edn. International Labour Office, Geneva

ILO (2019a) Handbook of procedures relating to international labour conventions and recommendations (Centenary edition 2019). International Labour Office, Geneva

ILO (2019b) Work for a brighter future - global commission on the future of work. International Labour Office, Geneva

Krause R (2018) The promotion of labour standards through international framework agreements. In: Gött H (ed) Labour standards in international economic law. Springer, Basel

OECD (2011) OECD guidelines for multinational enterprises. OECD Publishing, Paris 
Schlachter M (2019) Rezeption des Arbeitsvölkerrechts im Rahmen der ESC. In: Schlachter M, Heuschmid J, Ulber D (eds) Arbeitsvölkerrecht. Mohr Siebeck, Tübingen

Stoll PT (2018) International economic and social dimensions: divided or connected? In: Gött H (ed) Labour standards in international economic law. Springer, Basel

Stolzenberg H (2019) Inspection of the inspectors: is the European Commission sufficiently prosecuting violations of ILO conventions under the GSP regulation? Archiv des Völkerrechts 57(2):207-233

Teklè T (2018) Labour rights and the case law of the European Court of Justice: what role for international labour standards? Eur Lab Law J 9(3):236-262

Thouvenin JM (2015) Diffusion and leveraging of transnational labour norms by the OECD. In: Blackett A, Trebilcock A (eds) Research handbook on transnational labour law. Edward Elgar, Cheltenham

Waas B (2019) Die Normüberwachung durch den ILO-Sachverständigenausschuss für die Durchführung der Übereinkommen und Empfehlungen. Archiv des Völkerrechts 57(2):123-152

Bernd Waas is Full Professor of Labour Law and Civil Law at the Goethe University, Frankfurt am Main. He is a Member of the Committee of Experts on the Application of Conventions and Recommendations (CEACR) of the ILO. He is Coordinator both of the European centre of expertise in the field of labour law, employment and labour market policies (ECE) which assists the Directorate-General for Employment, Social Affairs and Inclusion of the European Commission, and of the European Labour Law Network (ELLN). Moreover, he is Chairman of the German chapter of the International Society for Labour and Social Security Law and a member of the advisory board of the Labour Law Research Network.

Open Access This chapter is licensed under the terms of the Creative Commons Attribution 4.0 International License (http://creativecommons.org/licenses/by/4.0/), which permits use, sharing, adaptation, distribution and reproduction in any medium or format, as long as you give appropriate credit to the original author(s) and the source, provide a link to the Creative Commons licence and indicate if changes were made.

The images or other third party material in this chapter are included in the chapter's Creative Commons licence, unless indicated otherwise in a credit line to the material. If material is not included in the chapter's Creative Commons licence and your intended use is not permitted by statutory regulation or exceeds the permitted use, you will need to obtain permission directly from the copyright holder.

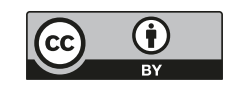

